\title{
LAST BIG CORPORATE SCANDALS IN BRAZIL: WHY INVESTORS DID NOT SEE IT IN THE ANNUAL REPORTS?
}

0 artigo foi aprovado e apresentado no XVIII International Conference in Accounting, realizado de 25/07 a 27/07 de 2018, em São Paulo (SP)

\begin{abstract}
This paper measures the level of information disclosure in the fight against corruption in sustainable reports disclosed by companies that participated in the last major corruption scandals in Brazil among 2013 to 2016 (Petrobras S.A., Odebrecht Organization, Brasil Foods S.A. and JBS S.A.); therefore, a not probabilistic sample was chosen. Content analysis through Novethic/SCPC survey (2006) was used to measure the level of disclosure and, among the results, the primary fact observed is that most of these companies exposed to corruption scandals did not modify their level of disclosed information in the fight against corruption, contradicting what was expected in a way that those companies which had higher levels of disclosure before the scandals continued following that path. Those results also revealed that information related to internal organization and a number of departments created to combat corruption were the most disclosed by the studied companies, indicating that these companies used of organized hypocrisy, that is, when the speech on their reports does not match with what is really done. This means that ethics committees created to diminish corruption, reporting systems, strict procedures related to contracting suppliers and other business partners, combined with other actions that encourage the implementation of anti-corruption training and systems were the most disclosed by the studied companies Since information about partnerships with nongovernmental entities and other organizations that have an interest in combating to this type of behavior were the least reported, the results showed off that it is required to look carefully to what is really happening and what it is disclosed by the companies' reports.
\end{abstract}

Keywords: Corporative Social Responsibility, Sustainability Report, Corruption, Disclosure.

\section{Arthur do Nascimento Ferreira Barros}

Mestrando em Ciências Contábeis pela Universidade Federal de Pernambuco (UFPE). Graduado em Ciências Contábeis pela Universidade Federal de Pernambuco (UFPE). Email: arthurnfbarros@hotmail.com

\section{Raimundo Nonato Rodrigues}

Doutor em Ciências Contábeis pela Universidade de São Paulo (USP). Mestre em Ciências Contábeis pela Universidade de São Paulo (USP). Graduado em Ciências Contábeis pela Universidade Federal do Ceará (UFC). Professor titular do Programa de Pós-Graduação em Ciências Contábeis da Universidade Federal de Pernambuco (UFPE) Email: rndg@uol.com.br

\section{Milena Rayane Lopes dos Santos}

Mestranda em Ciências Contábeis pela Universidade Federal de Pernambuco (UFPE). Graduada em Ciências Contábeis pela Universidade Federal de Pernambuco (UFPE). Email: milena_lopes22@hotmail.com 


\section{INTRODUCTION}

The discussion about sustainability becomes increasingly present in the deliberation lines carried out, both in the academic and in the business environment. The concept of sustainability involves three aspects: (1) environmental; (2) economic; and (3) social. However, acting in an economically, socially and environmentally sustainable path is currently one of the greatest challenges. The leaders of each organization must be aware that companies also have ethical responsibilities to contribute to the creation of a sustainable society (HOPWOOD; UNERMAN; FRIES, 2010).

Regarding the social perspective that sustainability covers, there is the concept of Corporate Social Responsibility (CSR), which is defined by the form of management related to an organization's ethics and lucidity to society and by the appreciation of responsibility as well as morality. CSR arises due to the impact of business decisions in the community, which should not be taken solely by the economic aspect, it is also necessary to take into account the interests of society (PESCADOR; BRIERE; NOVAK, 2016).

The companies which act according to the values of CSR are well regarded by society, a factor that contributes to the continuity of these companies (PESCADOR; BRIERE; NOVAK, 2016). On the other hand, those who do not operate on the values of CSR could become fragile, uncompetitive and risk both their image and reputation (PESCADOR; BRIERE; NOVAK, 2016). For instance, Siemens (2002), KBR/Halliburton (2004), BAE System (2005), and more recent national cases such as Petrobras (2014), Odebrecht (2015), JBS and BRF (2016), all involved in corruption schemes.

Concerning the last big corporate scandals in Brazil, the one instated in Petrobras S.A., between 2004 and 2014, was elected the second major case of corruption in the world by the Transparency International (MACEDO; YONEYA, 2016). It was discovered that the company Odebrecht was involved in bribery schemes with Petrobras S.A., ending with the arrestment of the former-president of the organization, Marcelo Odebrecht (BENDINELLI; MENDONÇA, 2017).

In relation to the scandal that involved organizations such as JBS S.A. and BRF S.A., the Federal Police of Brazil discovered that these companies participated in a scheme that bribed agricultural inspectors who worked for the ministry of agriculture in order to sell meat which was adulterated with chemical or overdue (ALESSI, 2017).

Corporate corruption can be defined as a criminal activity, law or regulation violation, committed by an organization, one individual or a group of individuals that belong to an organization (SONG; HAN, 2017). Corruption undermines social, political and economic development. It makes the services provided by the State reduced, as education, basic sanitation and public health, mainly for the less fortunate (JOSEPH et al., 2016), considering corruption favors the choice of more profitable investments, where the possibility of receiving bribery is greater, while the provision of basic services is neglected. As for economic growth, corruption distorts public investments, discourages foreign capital inflows, and encourages organizations to operate in the informal sector. Ultimately, there is loss of legitimacy on the market's economy and democracy (BRANCO, 2010).

Corporations are the main sources of corruption; nevertheless, they could also come up with solutions to this problem. Therefore, the fight against corruption corresponds to an (is a case of) opportunity to demand corporate social responsibility programs, with the goal of solving issues related to both corporate and social interests, such as the Transparency International. In spite of this, few studies approach the fight against corruption (BRANCO, 2010; SAEZ; BROWN, 2018). One of the ways to combat corruption is access to information, as it develops in environments characterized by a lack of transparency and occurs when decisions are taken with closed doors, away from the public eyes and the press (BENTO; BRINGEL, 2014).

A line for companies to make information available to society is through their sustainable reports, which are recent trends that have been expanding in the last two decades. There are several reasons for organizations to produce this type of report, but according to the literature, not only do they aim to be transparent and accountable, but also expect a financial return for being socially responsible (LESZCZYNSKA, 2012).

A critical view at corporate disclosures is essential in order to perceive discrepancies between what is published and what is actually done, once those companies normally use their sustainability reports as a tool of legitimacy (CHO et al., 2015). Nevertheless, evidence for such behavior is difficult to provide, despite the fact that many organizations are suspected of taking advantage of the massive publication of sustainable reports to strengthen their reputation without actually adopting environmental and social practices that are described in their reports (JACOMOSSI; CASAGRANDE; REIS, 2015).

Based on what was stated, this research aims to measure the level of information disclosure in the fight against corruption entrenched in those companies that have been involved in the last major corruption scandals in Brazil: Petrobrás S.A., Odebrecht Organization, Brasil Foods S.A. (BRF) and JBS S.A. between the years 2013 and 2016.

The relevance of this review is based on the importance of combating corporate corruption due to its impact on society, once the money diverted in those schemes could contribute to society's improvement and modify the negative conditions that a developing country suffers.

The current article is structured in five sections, including this first one, consisting of the introductory aspects in relation to the theme, followed by the theoretical foundation on the studied topic. In the third section, we show off the methodological aspects that involve the research. The last sections corresponds, respectively, to the main results obtained and the final considerations about the article. 


\section{LITERATURE REVIEW \\ 2.1 Corporate Social Responsibility}

A great number of authors argue that the definition of Corporate Social Responsibility, often referred as CSR, is still unclear. Because it is a recent, dynamic and even controversial material, its characterization involves subjects such as profits generation to the implementation of social actions. The literature on CSR is still so fragmented, with multiple and diverse approaches, that it furthers the several definitions and understandings about the topic (TEWARI; DAVE, 2012; HILLER, 2013; PESCADOR; BRIERE; NOVAK, 2016).

According to Simionescu and Dumitrescu (2014), there is no single definition whenever it comes to CSR and its role in society, but most of the authors that deal with Corporate Social Responsibility see an attempt by organizations to act in a legitimate way towards the society that they are inserted in (SIMIONESCU; DUMITRESCU, 2014; PESCADOR; BRIERE; NOVAK, 2016).

Operating on the ethical and moral perspectives, in the Corporate Social Responsibility approach, is portrayed as a pure case of companies acting responsibly and characterized as the right thing to do as a member of society (HILLER, 2013). It is safe to say that by acting according to the CSR perspective, the companies will not quit their economic goals and shareholder's interests, but quite the opposite, an organization is socially responsible when it performs its economic role in society within the ethical and acceptable legal norms (PESCADOR; BRIERE; NOVAK, 2016).

The CSR is used as a strategy to increase organization's reputation and, consequently, its profits. It reflects two approaches: (1) the shareholder's approach, based on the view that corporate social responsibility is to increase profits; and (2) the stakeholder's approach, that focuses on various interest groups directly or indirectly affected by organizations' decisions and actions. Profits should be seen more broadly, bypassing the financial concept and including social benefits such as: (1) value creation; (2) recognizing that the business operations are affected by social challenges; (3) and its ability to contribute to social challenges. (TEWARI; DAVE, 2012).

Corporate social responsibility is no longer an option for organizations. Companies, in general, have adhered to the concepts of CSR as part of the business strategy. Regardless of size, sector and country, organizations are acting in a socially responsible manner. One of the expositions for this phenomenon may be the pressure exerted by the external environment in the face of social expectations, media reports or the growth, in both number and quantity, of pressure groups (HILLER, 2013). Companies with a better corporate social performance are more willing to disclose their activities related to corporate social responsibility to the market, as a way to demonstrate their long-term interest as well as to differentiate themselves from other organizations (CHENG; IOANNU; SERAFEIM, 2014).

The economic situation has caused shareholders to rethink their business strategies and to consider environmental and social responsibility as important practices for society and economy. As the means of disseminating such practices, one of the most recent tactics to communicate CSR is the use of sustainable reports, which have been evolving in the last decade and have several nomenclatures: reports of corporate social responsibility; global citizenship report; or sustainability reports (TEWARI; DAVE, 2012; SIMIONESCU; DUMITRESCU, 2014).

Strategies that concern the fight against corruption can be included in the practices of CSR and communicates itself to the entire organization's members. It is emphasized that all initiatives of CSR, which involve anticorruption measures, must be communicated to the stakeholders, both internal and external (JOSEPH et al., 2016).

The disclosure of anticorruption measures is a method to insure that the management has social accountability; in addition, the performance on CSR helps to mitigate corruption exposure risk (JOSEPH et al., 2016; LOPATTA et al., 2016). According to Hoi and Lin (2012), CSR prevents and controls corruption in two ways: (1) extrinsic regulations that emphasize oversight and punishment; and (2) intrinsic motivation that emphasize integrity and self-monitoring.

CSR initiatives should be related to specific topics, such as corruption. On the other hand, few studies found a specific disclosure about corruption (WEYZIG, 2009). As stated by Joseph et al. (2016), there is a lack of substantive disclosure that deals with bribery and other corruption strategies in organizations, based on a literature review made by the authors.

Usually the academic researchers have focused in the main corruption causes, as economic, political and cultural factors, however, the interest in lucidity and combating corruption, as benefits caused by CSR, have received increased attention by researchers, scholars and international organizations in the last years (BRANCO, 2010; MACHADO, 2013; SIMIONESCU; DUMITRESCU, 2014; BRANCO; MATOS, 2016).

\subsection{Sustainability Reports}

For several years, sustainability has become significant in the business world. Transitions in the external environment increased concern with society and the environment, and structural changes in relations among government, business and society have reshaped public expectations of the role played by organizations in this new landscape. In the last decade, more and more organizations have dedicated in evaluating their performance through social and environmental aspects (LESZCZYNSKA, 2012; COFFEY; HIGGINS, 2016).

The number of investors who diversify their portfolios by investing in organizations committed to sustainable development is increasing (JACOMOSSI; CASAGRANDE; REIS, 2015). A survey conducted with more than 200 professionals by Ernst and Young (2015) showed an evolution of the importance of non-financial information when it is time to invest. 
According to the survey, $61.5 \%$ of the respondents considered relevant non-financial information pertinent to all sectors of the economy, while $70 \%$ considered integrated reports essential or important when making investment decisions. More in relation to the survey, $59.1 \%$ considered sustainability or social responsibility reports important when making investment decisions.

Due to the public harassment, companies are increasingly concerned about sustainability, in a way that producing sustainability reports has become a new trend in corporate disclosure (LESZCZYNSKA, 2012). In 2005, KPMG presented that $50 \%$ of the 250 largest companies in the world produced these kind of reports and in 2013 the percentage reached to $95 \%$ (COFFEY; HIGGINS, 2016).

Sustainability reports are based on the premise that organizations are linked with more interest groups than just their shareholders. They are a form of reporting information about economic, environmental and social impacts of the triple bottom line concept, corporate social responsibility and relevant developments in understanding the entity's risks and performance. All information presented in the report must be: (1) comprehensive; (2) reliable; (3) valid; and (4) comparable (LESZCZYNSKA, 2012; PANJAITAN, 2017).

It is expected that sustainable reporting increases public and company confidence in maintaining their customers, employees, and assets that influence the organization's financial performance. Therefore, these reports have a direct impact on the image, external evaluation and market value of the organizations that produce it. Consequently, the companies count on benefits for disseminating sustainable practices, like improving reputation and increasing financial performance (LESZCZYNSKA, 2012; JACOMOSSI; CASAGRANDE; REIS, 2015; PANJAITAN, 2017).

According to Blanc et al. (2017), the disclosure of anticorruption information could work as a tool in the fight against corruption for the following reasons: (1) it would help to hold organizations accountable for their performance and success in their efforts to combat corruption; (2) it would raise awareness in society; (3) it would encourage other organizations to adopt similar standards; and (4) it would heighten the possibility of putting into practice only what is really efficient for the fight against corruption, developing exclusively the necessary, as the most effective corporate governance practices.

On the other hand, sustainability reports usually focus on environmental, workplace safety, workers healthy and local community issues. The disclosure of Anticorruption information is usually practiced in a general way, broad and with few information, making the disclosure quality poor. Moreover, despite the importance of facing corruption, there is a lack of studies about the matter that only recently began to integrate the initiatives and policies of corporate social responsibility, as the Global Reporting Initiative and the United Nations Global Compact (DEEGAN, 2002; BLANC et al., 2017).

One of the characteristics of evaluating the quality of sustainable reports is lucidity, whereas the credibility of the report depends on the complete disclosure of all the processes, procedures and assumptions made in its preparation (LESZCZYNSKA, 2012). However, in a survey conducted by Leszczynska (2012) the studied reports omitted information on bribery and corruption, noncompetitive behavior and how companies deal with such matters. Actually, in the social sphere, the less exposed information was about anti-corruption policy, leading to the following question: are sustainability reports really serving their true purpose?

\subsection{Scandals}

This section intends to provide a brief of the corruption scandals concerning the companies studied in this article, aiming to supply further clarification of the events and showing the importance of combating corruption, taking into account that the scandals in question were based on public money that was deviated from the population and affected society in other matters. In addition, the section was divided according to the Federal Police operations "Car Wash" and "Weak Flesh".

\subsubsection{Car Wash}

According to Macedo and Yoneya (2016), the bribery scheme installed at Petrobras from 2004 to 2014, as stated by the NGO Transparency International, was the second largest corruption scandal on the planet. The scheme disclosure to the public occurred in March, 2014 by an operation conducted by the Brazilian Federal Police called Car Wash (COSTA et al., 2015).

The intention of this operation was to analyze a money diversion and laundering system within the company, on which participated directors and managers, famous companies in the Brazilian civil construction sector, as well as politicians. According to the news website "Uol Economia" in 2015, the scheme operated through fraudulent bidding, on which the engaged agreed among themselves who would be winning and later they overpriced the construction. In addition, part of that money coming from overbilling was diverted to pay bribes (COSTA et al., 2015).

According to a newspaper article written in 2014 by the magazine "Época", among the builders involved in the scandal was Odebrecht, the corporation which contributed to the political campaign of impeached President Dilma Rousseff (2014-2016) with US\$ 8 million in 2010 through money evasion, as consequence for a previously agreed win in a bidding of Petrobras for US\$ 825 million. 
Until May 2015, Odebrecht had not suffered with the investigations of Car Wash, however, that changed in June 2015, when Marcelo Odebrecht, current CEO, was arrested. Since then, the builder, one of the most important in the Latin America, had to sell assets to decrease debts, was forbidden of doing business with Latin America countries and, moreover, lost seventy seven employees which were involved in the corruption scheme and, in order to reduce their sentence, had to collaborate with the police, signing a deal (BENDINELLI; MENDONÇA, 2017).

The scheme discovered at Odebrecht was older and more organized than the one found on Petrobras. Odebrecht, along with one of its petrochemical subsidiaries, paid more than US\$ 1 billion in bribes to officials, political parties and government representatives in more than 12 countries, in order to guarantee that the companies would win any bidding that they disputed. The Federal Police, according to "Uol Economia" in 2016, discovered an exclusive department created to manage the bribe payments called "Structured Operations Division", mainly operating in 2014. However, there are indications that this scheme goes even further back in time, beginning around 1985, but nothing confirmed.

As stated by the Brazilian Federal Public Prosecutor (2017), Odebrecht executives were arrested for corruption crimes and money laundry trough contracts signed with Petrobras. In addition, it was proved that the bribe was used to pay top managers of the Public Company as others government agents.

\subsubsection{Weak Flesh}

According to Alessi (2017), who wrote a report for the newspaper "El País Brasil", both companies BRF and JBS were investigated by the Federal Police in an operation called Weak Flesh. It was a bribery scheme involving agricultural inspectors from the Ministry of Agriculture, where the companies would sell low quality products, adulterated by chemicals or even meats outside their shelf life. Some of these adulterated foods were even provided to students at public schools.

Mentioned by a report on the newspaper "O Globo" in 2017, this was one of the largest operations of the Federal Police, involving more than 1,000 police officers and over 300 judicial mandates. Among those involved were a Governor and the Minister of Justice - another minister of President Michel Temer involved in a corruption scandal. In Brazil, the ministers are chosen by the president and are considered people of confidence to the maximum authority of the Republic.

After the executives' arrestments from both companies, other schemes were revealed through a plea bargain made with the defendants. According to "BBC Brazil" in 2017, the confessions made by JBS entrepreneurs hit the national political system and the political parties that have been taking turns in power in recent years. The participation of presidents, Luiz Inácio Lula da Silva (2003-2011), Dilma Rousseff (2014-2016) and Michel Temer (2016-2018), as well as the former president of the National Development Bank and former Minister of Finance, Guido Mantega, were affirmed in the pleas. Still on this matter, it was claimed that they even bought votes during the impeachment process.

In another report, this time held by the "G1" in 2017, the JBS executive revealed another corruption scheme: with the purpose of tax evasion, more precisely the tax on goods and services circulation known as ICMS, a total of R\$150 million was paid in exchange for $\mathrm{R} \$ 500$ million in discounts regarding ICMS.

The Weak Flesh operation not only pointed the existence of a corruption scheme involving slaughterhouses and members of the Ministry of Agriculture, but also questioned the quality of the products sold by the biggest companies in the Brazilian food sector (NOVAES, 2017).

\section{METHODOLOGY}

We apply a content analysis technique, which is useful to analyze the sustainable reports in our sample, thus to devise a measure of the disclosure level of anti-corruption information. It consists of a technique formed by systematic procedures that allow the elaboration of quantitative or non-quantitative measures, which is capable of allowing inferences about the subject (CAVALCANTE; CALIXTO; PINHEIRO, 2014).

Through this technique, the researcher seeks to comprehend the characteristics that are behind the fractions of messages that are being studied. It is possible to classify the information disclosed in reports into several elements which presents the aspects that will be interpreted (BRANCO, 2010; CÂMARA, 2013).

The simplest form of content analysis was used, which consists of perceiving the existence or the lack of information about a specific issue, where at least one information item needs to be disclosed under each studied aspect (BRANCO; MATOS, 2016; HANIFFA; COOKE, 2005).

\subsection{Sample}

The sample is composed of sustainable reports from companies involved in the last major corporate scandals in Brazil, according to the magazine "Exame" and the newspapers "G1" and "O Globo": Petrobrás S.A., Odebrecht, JBS S.A. and BRF S.A. The Federal Police revealed the scandals in 2014, 2015 and 2017, respectively. A non-probabilistic sample was used, which is selected through the subjective criteria of the researcher (MAROTTI et al., 2008).

Among the types of non-probabilistic samples, a judgment sample was chosen, which seeks elements that are a good source of precise information and when an intentionally biased sample is necessary (MAROTTI et al., 2008; OLIVEIRA, 2001), although it is not possible to generalize because the population it is not random (FIALHO, 2013). Further- 
more, it is not the intention of this study to do generalizations, but to observe the companies' behavior in relation to their disclosure of the topic in matter.

The analyzed reports correspond to the periods from 2013 to 2016 and were extracted from the companies' respective websites exhibited in Table 1.

Table 1 - Sample Composition

\begin{tabular}{cccc} 
Enterprise & Economic Sector & Scandal Year & Website \\
\hline BRF S.A. & Foods & 2017 & http://ri.brf-global.com/default_pt.asp?idioma=0\&conta=28 \\
JBS S. A. & Foods & 2017 & http://jbss.infoinvest.com.br/ \\
Petrobrás S.A. & Oil and Gas & 2014 & http://www.investidorpetrobras.com.br/ \\
Odebrecht & Civil Construction & 2015 & https://www.odebrecht.com/pt-br/investidores \\
\hline
\end{tabular}

Source: Prepared by the authors.

\subsection{Disclosure Level}

According to Haniffa and Cooke (2005, p. 404), "an essential element of content analysis is the selection and development of categories into which content units can be classified". To analyze the level of information disclose in the fight against corruption, the Novethic/SCPC study (2006) was used, as well as in other studies (BRANCO, 2010; MACHADO, 2013; BRANCO; MATOS, 2016).

According to Branco (2010), the Novethic/SCPC study in 2006 was about information disclosure practices that deal with anticorruption policies implementation and commitment. Reports, websites and sustainability reports of the observed companies were analyzed. The study revealed that $80 \%$ of the anticorruption information disclosed by the sample could be considered as incomplete or indifferent, and in average only one fourth of the information is expected to be disclosed. Based on this work, six categories of disclosure on anti-corruption are defined:

1) Commitment to the fight against corruption (reference in the corporate codes of ethics or conduct, membership of the UN Global Compact and references to the 10 principles, etc.);

2) Internal organization to stop corruption (ethics committee to deal with this issue, dedicated manager or some type of department, reporting system, etc.);

3) Exposure to risk (risk assessment to identify areas that may potentially be exposed to corruption, policies for high-risk areas, etc.);

4) Implement procedures related to employees (training and communication on anticorruption, etc.);

5) Implement procedures related to suppliers and other business partners (actions taken to encourage the implementation of anti-corruption training and monitoring systems, etc.); and

6) Initiatives in partnerships with non-governmental organizations (NGOs) and other organizations.

The level of disclosure in companies is measured through a ranking from 0 to 6 , which is punctuated when the company discloses in its sustainable report some kind of information on the six topics mentioned above. For each type of information disclosed on a topic, the company acquires a point.

\section{RESULTS}

According to the ranking made to measure the disclosure level of the analyzed entities, based on the Novethic/ SCPC study (2006), there are six categories. The following table will be discussed:

Table 2 - Disclosure Level

\begin{tabular}{cccccc}
\hline \multirow{2}{*}{ Company } & $\mathbf{2 0 1 3}$ & $\mathbf{2 0 1 4}$ & $\mathbf{2 0 1 5}$ & $\mathbf{2 0 1 6}$ & Mean \\
\cline { 2 - 5 } & Disclosure & Disclosure & Disclosure & Disclosure & \\
\hline Petrobras & 6 & 6 & 6 & 6 & 6 \\
JBS & 5 & 5 & 5 & 4 & 4,75 \\
BRF & 4 & 5 & 5 & 5 & 4,75 \\
Odebrecht & 0 & 2 & 3 & 6 & 2,75 \\
\hline
\end{tabular}

Source: Prepared by the authors. 
The public has known the scandals involving the companies in 2014 (Petrobrás); 2015 (Odebrecht); and 2016 (BRF and JBS). Both Petrobras and food companies BRF and JBS had high levels of disclosure in the fight against corruption previous to the Federal Police operations that exposed illegal activities to which members of the organizations were involved. Moreover, according to Table 3, Petrobras always had a maximum score referring to the level of information dissemination on combating corruption.

For instance, the message of the president of Petrobras in 2013 sustainability report contained:

In 2013, we completed ten years of participation in the United Nations Global Compact. We reaffirm that we will continue developing actions to progress more and more towards the ten principles of the initiative, focused on the areas of ... and fight against corruption (PETROBRAS, 2013, pp. 5).

As stated by Branco and Matos (2016), public companies disclose more sustainable information, since they depend on political and moral support than the private ones (GHAZALI, 2007; TAGESSON et al., 2009).

Another example is in JBS's sustainability report (2016, pp. 41), "In all jurisdictions where JBS operates, ethics and anti-corruption training is offered to ensure compliance with social laws". In addition, in BRF sustainability report was written:

In the BRF Transparency manual, employees of the Company are expressly prohibited from engaging in corruption or engaging in the granting of a bribe, passively or actively, either directly or indirectly. It is prohibited to frustrate, deceive, prevent or disturb public or private bidding procedures (BRF, 2016, pp. 122).

However, a standard present in a business code or manual does not satisfy the condition that all employees will comply with this standard. Nevertheless, it was clearly stated in BRF annual report that there were control measures to avoid such risks:

We maintain a routine of evaluating risks of corruption that are identified and classified according to their degree of criticality and priority. Based on a risk classification, the Compliance Department draws up an action plan to mitigate these risks (BRF, 2016, pp. 26).

Therefore, for these companies, the fight against corruption was clearly one of their goals, some with departments specialized in evaluating risks of corruption and fighting them. However, in some away, these measures to combat corruption failed and these companies became the last big corporate scandals.

Unlike the other companies, the construction firm Odebrecht had a low level of information disclosure in the fight against corruption. Although, after the scheme that the company operated in was disclosed, the entity began to disclose information on the fight against corruption for all six categories present in the Novethic / SCPC study (2006).

For instance, the word "corruption" is not mentioned in the sustainability reports of Odebrecht in 2013 and 2014. Only on 2015's report, in a presidential message from the administrative council, the following is mentioned: "We understand, however, that the problem of corruption deserves attention, care and extreme fighting, and that it is necessary to show the lawfulness of any actions involving public resources" (ODEBRECHT, 2015, pp. 11). This is when the company started to demonstrate concernment on the subject.

This low level of disclosure goes against the literature (BRANCO; MATOS, 2016; HANIFFA; COOKE, 2005), which assumes that organizations with greater visibility of the public, that operate in areas that can cause major environmental impacts, or in sectors with a high risk of corruption, such as the construction, oil and gas, telecommunications and public utilities, disseminate more information on social responsibility.

According to Saenz and Brown (2018), it is not surprising that the constructor sector is characterized as the most propitious to corruption, due the complex nature way of conducting business, beyond the involving of many different parts.

The characteristics that made this sector more complicated than others are: (1) great public money circulation; (2) high levels of competiveness, due to the bidding processes; (3) lack of transparency in the project selection processes; (4) political interference; (5) monopolistic nature; (6) low profitability margins; and (7) close relations between contractors (KRISHNAN, 2009).

Lastly, after the scandal became public, 2016's report scores the highest level of information disclosure in the fight against corruption, as expected. This result are consistent with the ones found by Saenz and Brown (2018), were the company Odebrecht also got high levels of anticorruption disclosure in 2016. That could be explained by the fact that the company needs to regain the public's trust and that this can be done through the annual report (LESZCZYNSKA, 2012; JACOMOSSI; CASAGRANDE; REIS, 2015; PANJAITAN, 2017).

As the data collection of this article occurred prior to the disclosure of 2017's sustainable reports of BRF and JBS companies, it was not possible to analyze the disclosure level for these companies after the bribe schemes were revealed. However, BRF's sustainable report of 2016 mentioned that the company is not involved with the scandals discovered by the Federal Police of Brazil, and does not support this type of behavior. In addition, it is expected that the companies' reports will reach the maximum score in the information disclosure in the fight against corruption, as is the Odebrecht report. 
Besides Odebrecht sustainability report, all the others analyzed reports showed concern and measures about the fight against corruption as expected. However, even then, corruption practices occurred in the organizations. This gap between what is disclosed and what really happens it is called organizational hypocrisy (CHO et al., 2015).

According to Cho et al. (2015), most of companies only disclose environmental and social information in their reports to gain legitimacy, position and promote private interests. In addition, organized hypocrisy allows companies decrease some stakeholder's pressure for sustainable information.

Organizational hypocrisy is related with some facts used by companies to gain legitimacy. I In this case, according to the literature, the studied companies used the reputation façade, on which organizations display corporate values, mission and codes of ethics, for example, to achieve goals or cover performance from some groups of stakeholders and even the press (CHO et al., 2015).

Although, as stated by Christensen, Morsing and Thyssen (2013), the disparity between companies' words and their actions is not necessarily a bad thing, in some cases this discrepancy has the potential to improve the measures disclosed by those organizations and that have not been applied. In fact, the differences between words and actions can be important to move forward the CSR field.

Ordinarily, after exposing their flaws, companies suffered with intense critique. Thus, gradually, what was once disclosed as organizational hypocrisy could become sustainable practices, which improve CSR and contribute to society (CHRISTENSEN; MORSING; THYSSEN, 2013).

In relation to the most publicized categories, the ones most reported in the time interval studied by the analyzed companies were categories 2 and 5, contrary to other research results (BRANCO, 2010; MACHADO, 2013; BRANCO; MATOS, 2016). Category 2 corresponds to internal organization to combat corruption, such as ethics committees, reporting system, departments to deal with this issue, etc. As JBS did in 2015's annual report when mentioning that in the same year the Corporate Compliance Directorate was created and one of its first measures was the reedition of the Manual of Ethical Conduct, a document that contains guides lines about expected behavior on anticorruption practices, money laundry and conflict of interests (JBS, 2015).

Category 5 is about procedure implementation related to suppliers and other business partners, as actions that encourage the implementation of anti-corruption training and systems. As stated by Petrobras in 2013's sustainability report: "All our suppliers and commercial partners are contemplated in our guidelines about anticorruption policies and procedures" (PETROBRAS, 2013, pp. 16).

In general, the other categories were mentioned on a regular basis in sustainable reports, as shown in Table 4, with the exception of category 6 , which was the least cited and refers to partnerships with nongovernmental entities or other organizations that have interests in combating this type of behavior, corroborating with other researches (BRANCO, 2010; MACHADO, 2013; BRANCO; MATOS, 2016).

Table 3 - Categories of Disclosure

\begin{tabular}{|c|c|c|c|c|c|c|}
\hline Categories & 2013 & 2014 & 2015 & 2016 & Total & Mean \\
\hline $\begin{array}{l}\text { Commitment to the fight } \\
\text { against corruption }\end{array}$ & 3 & 3 & 4 & 4 & 14 & 3,5 \\
\hline $\begin{array}{c}\text { Internal organization to com- } \\
\text { bat corruption }\end{array}$ & 3 & 4 & 4 & 4 & 15 & 3,75 \\
\hline Exposure to risk & 2 & 3 & 3 & 3 & 11 & 2,75 \\
\hline $\begin{array}{l}\text { Procedure implementation } \\
\text { related to employees }\end{array}$ & 3 & 3 & 3 & 4 & 13 & 3,25 \\
\hline $\begin{array}{l}\text { Procedure implementation } \\
\text { related to suppliers and other } \\
\text { business partners }\end{array}$ & 3 & 4 & 4 & 4 & 15 & 3,75 \\
\hline $\begin{array}{l}\text { Initiatives in partnerships with } \\
\text { NGOs }\end{array}$ & 1 & 1 & 1 & 2 & 5 & 1,25 \\
\hline
\end{tabular}

Source: Prepared by the authors.

The only company to affirm partnership with a NOG in all the years analyzed was Petrobras, which stated the following: "In the fighting against corruption, we keep our commitments with the Partnering Against Corruption Initiative (Paci), Extractive Industries Transparency Initiative (Eiti) and the Business Pact for Integrity and against Corruption” (Petrobras, 2013, pp. 12).

According to Table 4, it's possible to observe which categories of disclosure in the fight against corruption were the most disclosed by the companies in their respective sustainable reports over the analyzed years (4 years). 
As example, concerning category 1 which deals with the commitment to the fight against corruption, Petrobras states:

... we implemented in the second half of 2013 the Corruption Prevention Program, which reaffirms the commitment of the Board of Directors of Petrobras and its employees to ethics and transparency in our organization. The program is in line with national and international initiatives to combat fraud and corruption, as well as the laws of the countries in which the company operates, with positive impacts on the relationship with all its stakeholders (PETROBRAS, 2013, p. 5).

In Odebrecht's case, which is the company with the lowest level of disclosure, categories 3 and 4 are the least disclosed in its annual reports. Category 3 corresponds to risk exposure and, according to literature, the bases material sector has a greater risk of corruption, the same with the oil and gas sector (BRANCO; MATOS, 2016), as it is possible to observe in the following statement made by the company: "We understand, however, that the problem of corruption deserves attention, extreme care and combat, and that it is necessary to show the legality of any actions involving public resources (ODEBRECHT, 2015, p. 7).

Still about this specific matter, Odebrecht only disclosed information about the risk of corruption after the corruption schemes inside the company were exposed, while Petrobras and JBS were already disclosing information about this category before the scandals were revealed.

In relation to the procedure implementations related to employees, BRF (2016) stated:

Over the last year, we have implemented several initiatives that reinforce our Ethics and Integrity Program, with emphasis on: reinforcing and disseminating a culture of ethics, respect and transparency by conducting face-to-face training for various internal audiences. Throughout 2016, 1.288 employees, with a special focus on leadership and senior management, were trained face-to-face in matters related to the BRF Transparency Manual, as well as the Company's anticorruption policies and practices (BRF, 2016,p. 25)

Therefore, regardless of whether or not these companies spread that they are exposed to the risk of corruption, and were committed through internal procedures to combat corruption, they have participated in the country's biggest corporate corruption scandals.

As observed, efforts to disclose anticorruption measures and actions can be used deceptively (SAENZ; BROWN, 2018). That explains the reason why, when it comes to CSR, accountability and sustainability, these practices are generally considered suspicious and neglected (CHRISTENSEN; MORSING; THYSSEN, 2013).

According to Cho et al. (2015) and Michelon et al. (2016), the critics that involve sustainability reports are generally related to the fact that they are used only as tools of legitimacy and/or to secure the interests of organizations in society, especially when there is some kind of legitimacy crisis.

Table 4 - Amount of time the category was disclosed between 2013 and 2016

\begin{tabular}{|c|c|c|c|c|c|c|}
\hline \multirow[b]{2}{*}{ Company } & \multicolumn{6}{|c|}{ Category } \\
\hline & $\begin{array}{l}\text { Commit- } \\
\text { ment to the } \\
\text { fight against } \\
\text { corruption }\end{array}$ & $\begin{array}{l}\text { Internal } \\
\text { organization } \\
\text { to combat } \\
\text { corruption }\end{array}$ & $\begin{array}{c}\text { Exposure to } \\
\text { risk }\end{array}$ & $\begin{array}{c}\text { Procedure } \\
\text { implementa- } \\
\text { tion related } \\
\text { to employ- } \\
\text { ees }\end{array}$ & $\begin{array}{l}\text { Procedure } \\
\text { implementa- } \\
\text { tion related } \\
\text { to suppliers } \\
\text { and other } \\
\text { business } \\
\text { partners }\end{array}$ & $\begin{array}{l}\text { Initiatives in } \\
\text { partnerships } \\
\text { with NGOs }\end{array}$ \\
\hline Petrobras & 4 & 4 & 4 & 4 & 4 & 4 \\
\hline $\mathrm{BRF}$ & 4 & 4 & 3 & 4 & 4 & 0 \\
\hline JBS & 4 & 4 & 3 & 4 & 4 & 0 \\
\hline Odebrecht & 2 & 3 & 1 & 1 & 3 & 1 \\
\hline
\end{tabular}

Source: Prepared by the authors.

The results on the level of exposure regarding the fight against corruption show that three out of four companies had good levels of disclosure, even before the cases were exposed. So, could just publicizing the intention to fight corruption enough for companies to deal with this illness? It is necessary to take a critical look at corporate disclosures, in order to perceive possible discrepancies between what is published and what is actually done (JACOMOSSI; CASAGRANDE; REIS, 2015)? There is not only a lack of disclosure about this matter, based on a literature review about corruption and CSR, but when companies do bring this matter to public attention, like in this specific case, most of what is disclosed does 
not correspond to the what it is actually done (CHO, et al., 2015; JOSEPH et al., 2016).

\section{CONCLUSION}

Corruption is a global issue and is characterized as an obstacle in the sustainable development of society. As companies are one of the main sources of corruption, it is expected that the means to combat corruption will emerge from them, due to the social responsibility that organizations have.

One suggestion to combat corruption is to provide information available to society. For companies to continue their operations, they must become legitimate to the community in which they operate. In addition, through sustainable reporting, organizations are able to make information available to their stakeholders.

However, it is necessary to have a critical view on the disclosures made by the companies, in order to perceive eventual disconnections between what is published and what is actually practiced (JACOMOSSI; CASAGRANDE; REIS, 2015). As it has been seen over the years, a number of organizations take advantage of the sustainable reports release to strengthen their image without even taking any of the sustainable measures outlined in their reports (CHO et al., 2015).

This research is justified by the increasing number of surveys carried out involving corporate social responsibility and sustainable reporting (LESZCZYNSKA, 2012; CHENG; IOANNU; SERAFEIM, 2014). Furthermore, it is due to the importance of combating corporate corruption and the great social impact this fight brings. Therefore, this search aimed to measure the level of information disclosure in the fight against corruption in companies that were involved in the last corruption scandals in Brazil, from 2013 to 2016.

According to results, the studied companies had most amount of disclosed information about internal organization to combat corruption, such as ethics committees, reporting system, departments to deal with this type of issues and procedure implementation related to suppliers (category 2) and other business partners; as actions that encourage the implementation of anti-corruption training and systems (category 5).

Then again, information about partnerships with nongovernmental entities or other organizations that have interest in combating this type of behavior (category 6) were the least reported, as seen in other papers (BRANCO, 2010; MACHADO, 2013; BRANCO; MATOS, 2016).

Concerning the disclosure levels, Petrobras, BRF and JBS had high rates of information disclosure regarding the fight against corruption over the years before the scandals. Only the company Odebrecht had low levels of disclosure and, after the scandals, it started to disclosure more anticorruption information, as expected.

About the construction sector, it is known as the most propitious to corruption, due to the complex nature way of conducting business, the public money circulation, the lack of transparency, political interference, monopolistic nature, beyond involving many different parts (KRISHNAN, 2009; SAENZ; BROWN, 2018).

However, if most of the studied companies had high levels of disclosure about anti-corruption information, how did they suffer from large bribe schemes and misappropriation over the years? Is there no social responsibility in sustainable reporting and most organizations only make this disclosure to avoid pressure from outside groups (PANJAITAN, 2017)?

The results of this research showed that the level of information disclosure in the fight against corruption does not match the reality of what happens inside of these organizations, probably because they used of organizational hypocrisy to gain legitimacy and/or decrease the stakeholder's pressure using a reputational face (CHO et al., 2015). However, nothing is completely loss; now an opportunity arises and it is up to them to improve their combat systems, preventing other cases and enhancing their CSR (CHRISTENSEN; MORSING; THYSSEN, 2013).

For any following researches, it is proposed the relation of corporate governance practices, which correspond to measures of protecting the investor's capital, with this level of information disclosure in the fight against corruption, in order to identify the failures that allow this sort of action to occur in organizations and harm society.

The presented paper contributed with prevailing literature on the subject, allowing the results found to be compared with the other searches that have already lessoned in the area. Beyond that, it proves the urge for more research and investigation involving this theme. Some of the limitations of this studied case are the methodology used to determine the disclosure level of the companies and the quantity of information in the sample, since the sample is non-probabilistic, so the results cannot be generalized. This paper does not verify the quality of the disclosed information, but only the existence of such data. Due to the historical corruption problems the country has always faced, it is possible to say that the theme is a promising area of research to be accomplished.

\section{REFERENCIES}

ALESSI, G. Operação carne fraca da PF coloca JBS e BRF na mira por esquemas de corrupção. El País Brasil, Brasília, Mar. 2017, Disponível em: < https://brasil.elpais.com/brasil/2017/03/17/politica/1489761743_696597.html>. Acesso em: 8 jan. 2018.

BENDINELLI, T.; MENDONÇA, H. Odebrecht: o império que perdeu a guerra para a Lava Jato. El País, São Paulo, Fev. 2017. Disponível em: <https://brasil.elpais.com/brasil/2017/01/30/politica/1485800226_876385.html>. Acesso em: 8 jan. 2018.

BENTO, L. V.; BRINGEL, P. O. M. Limites à transparência pública das empresas estatais: Análises da aplicação da Lei de Acesso a Informação (Lei n ${ }^{\circ} 12.527 / 2011$ ) a empresas públicas e sociedades de economia mista. In: CONGRESSO NACIONAL DO CONPEDI, 23., 2014, João Pessoa. Anais... João Pessoa: 2014. 
BLANC, R. et al. Disclosure Responses to a Corruption Scandal: The Case of Siemens AG. Journal of Business Ethics, p. 1 - 17, 2017.

BRANCO, C. M. Informações sobre combate à corrupção nos relatórios de sustentabilidade das empresas portuguesas. Estudos do ISCA, v. 4, n. 2, p. 1 - 16, 2010

BRANCO, C. M.; MATOS, D. The fight against corruption in Portugal: evidence from sustainability reports. Journal of Financial Crime, v. 23, n. 1, pp. $132-142,2016$.

BRASIL, G. Declarações da Odebrecht: entenda o maior escândalo de corrupção do país. G1, Brasília, Abr. 2017, Disponível em: <http://g1.globo.com/jornal-hoje/noticia/2017/04/delacoes-da-odebrecht-entenda-o-maior-escandalo-de-corrupcao-do-pais. html>. Acesso em: 8 jan. 2018.

BRASIL. Ministério Público Federal. Caso Lava Jato: Entenda o Caso. Brasília, [2014?]. Disponível em: <http://www.mpf. mp.br/pr/para-o-cidadao/caso-lava-jato/entenda-o-caso>. Acesso em: 8 jan. 2018.

BRF S.A. Relatório Anual de Sustentabilidade de 2016. São Paulo, 2016. Disponível em: < http://ri.brf-global.com/>. Acesso em: 8 jan. 2018.

CÂMARA, R. H. Análise de conteúdo: Da teoria à prática em pesquisas sociais aplicadas às organizações. Revista Interinstitucional de Psicologia, v. 6, n. 2, p. 179 - 191, 2013.

CAVALCANTE, R. B.; CALIXTO; P;; PINHEIRO, M. M. K. Análise de Conteúdo: Considerações gerais, relações com a pergunta de pesquisa, possibilidades e limitações do método. Informação e Sociedade: Estudos, v. 24, n. 1, p. 13 - 18.

CHENG, B.; IOANNOU, I.; SERAFEIM, G. Corporate Social Responsability and Access to Finance. Strategic Management Journal, v. 35, p. 1 - 23, 2014.

$\mathrm{CHO}, \mathrm{C} . \mathrm{H}$. et al. Organized hypocrisy, organizational façades, and sustainability reporting. Accounting, Organizations and Society, v. 40, p. $78-94,2015$.

CHRISTENSEN, L. T.; MORSING, M.; THYSSEN, O. CSR as aspirational talk. Organization, v. 20, n. 3, p. 372 - $392,2013$.

COFFEY, B.; HIGGNIS, C. Improving how sustainability reports drive chance: a critical discourse. Journal of Cleaner Production, v. 136, p. $18-29,2016$

COSTA, Y. et al. Estudo de caso: Gerenciamento de crise da Petrobrás em meios digitais após a deflagração da operação Lava Jato. In: CONGRESSO DE CIÊNCIAS DA COMUNICAÇÃO NA REGIÃO NORDESTE, 17., 2015, Natal. Anais... Natal: 2015.

DEEGAN, C. Introduction: The legitimising effect of social and enviromental disclosures - a theorical foundation. Accouting, Auditing \& Accountability Journal, v. 15, n. 3, p. 282 - 311, 2002.

ERNST \& YOUNG GLOBAL LIMITED. Emerging risk and stranded assets have investors looking for more nonfinancial reporting. Londres: [s.n], 2015.

GHAZALI, N. A. M. Ownership structure and corporate social responsibility disclosure: some Malaysian evidence. Corporate Governance: The international journal of business in society, v. 7, n. 3, p. $251-266,2007$.

HANIFFA, R.; COOKE, T. The impact of culture and governance on social reporting. Journal of Accounting and Public Policy, v. 24 , n. 5 , p. $391-430,2005$. 2013.

HILLER, J.S. The Benefit Corporation and Corporation Social Responsibility. Journal of Business Ethics, v. 118, p. 287 - 301 ,

HOI, Y.-H.; LIN, C.-Y. Preventing Corporate Corruption: The Role of Corporate Social Responsibility Strategy. International Journal of Business and Behavioral Sciences, v. 2, n. 1, p. 12 - 22, 2012.

HOPWOOD, A. G.; UNERMAN, J.; FRIES, J. Accounting for sustainability: Practical insights. London: Earthscan, 2010.

JACOMOSSI, F. A.; CASAGRANDE, R. M.; REIS, L. G. O isomorfismo nos relatórios de sustentabilidade: Uma análise das empresas brasileiras que compõe o Dow Jones sustainability index. Revista de Gestão Ambiental e Sustentabilidade, v. 4, n. 2, p. $49-64,2015$.

JBS S.A. Relatório Anual de Sustentabilidade 2016. São Paulo, 2016. Disponível em: < http://jbss.infoinvest.com.br/>. Acesso em: 8 jan. 2018.

JOSEHP, C. et al. A comparative study of anti-corruption practice disclosure among Malaysian and Indonesian Corporate Social Responsibility (CSR) best practice companies. Journal of Cleaner Production, v. 112, p. 2896 - 2906, 2016.

KRISHNAN, C. Combating Corruption in the Construction and Engineering Sector: The Role of Transparency International. Leadership and Management in Engineering, v. 9, n.3, p. $112-114,2009$.

LESZCZYNSKA, A. Towards shareholder's value: an analysis of sustainability reports. Industrial Management \& Data, v. 112, n. 6, p. $911-928,2012$.

LOPATTA, K. et al. Corruption, Corporate Social Responsibility and Financial Constraints: International Firm-level Evidence. European Management Review, v. 14, n. 1, p. $47-65,2016$.

LOPES, P. Esquema de propina da Odebrecht funcionava desde o governo Sarney. Uol Economia, São Paulo, Mar. 2016, Disponível em: <https://noticias.uol.com.br/politica/ultimas-noticias/2016/03/26/esquema-de-propina-da-odebrecht-funcionava-desde-governo-sarney.htm>. Acesso em: 8 jan. 2018.

MACEDO, F.; YONEYA, F. Petrobrás é o segundo maior escândalo de corrupção do mundo, aponta Transparência Internacional. Estadão, São Paulo, Fev. 2016. Disponível em: <http://politica.estadao.com.br/blogs/fausto-macedo/petrobras-e-o-segundo-maior-escandalo-de-corrupcao-do-mundo-aponta-transparencia-internacional/>. Acesso em: 8 jan. 2018. 
MACHADO, V. Divulgação de informação sobre combate à corrupção nos relatórios de sustentabilidade: $\mathbf{O}$ caso do setor energético brasileiro. 2013. Dissertação (Mestrado em Economia e Gestão do Ambiente) - Faculdade de Economia, Universidade do Porto, Porto, Portugal, 2013

MICHELON, G. et al. Behind camouflaging: traditional and innovative theoretical perspectives in social and environmental accounting research. Sustainability Accounting, Management and Policy Journal, v. 7, n. 1, p. 2-25, 2016.

NAGANO, R. T. et al. A evolução dos relatórios de sustentabilidade e a necessidade da obrigatoriedade de sua asseguração por terceiros. In: SIMPÓSIO INTERNACIONAL DE GESTÃO DE PROJETOS E I SIMPÓSIO INTERNACIONAL DE INOVAÇÃO E SUSTENTABILIDADE, 2. 2013, São Paulo. Anais... São Paulo: 2013.

NOVAES, M. JBS e BRF, de "campeãs nacionais" a suspeitas de vender carne vencida. El País Brasil, Mar. 2017, Disponível em: <https://brasil.elpais.com/brasil/2017/03/17/politica/1489763244_536570.html>. Acesso em: 8 jan. 2018.

NOVETHIC/SCPC. Transparence en matière de lutte anti-corruption - Le traitement de l'enjeu "corruption" dans le reporting développement durable des entreprises du CAC 40 en 2004 et 2005. 2006, Disponível em: < <https://www.novethic.fr/fileadmin/user_upload/tx_ausynovethicetudes/pdf_complets/Novethic $\% 20$ SCPC $\% 20$ Etude $\% 20$ RSE $\% 20$ Transparence $\% 20$ de $\% 201$ a $\% 20 l u t t e \% 20$ contre $\% 20 l a \% 20$ corruption $\% 20$ des $\% 20$ entreprises $\% 20$ du $\% 20$ CAC 40 septembre $\% 202006$.pdf>. Acesso em: 8 jan. 2018.

ORGANIZAÇÃO ODEBRECHT. Odebrecht 2015. Rio de Janeiro, 2015. Disponível em: < https://www.odebrecht.com/pt-br/ investidores>. Acesso em: 8 jan. 2018.

PANJAITAN, I. The influences of sustainability report and corporate governance toward financial and entity market performance with political visibility as moderating variable. Binus Business Review, v. 8, n. 1, p. 61 - 66, 2017

PEIXOTO, N. O.; MARTINS, V. F. (2015). Relato Integrado e a convergência com relatórios de sustentabilidade: Um estudo em empresas brasileiras. Revista de Auditoria, Governança e Contabilidade, v. 3, n. 7, p. 23 - 36, 2015

PESCADOR, S. V. B.; BRIERE, F; NOVAK, P. O impacto dos resultados da avaliação da responsabilidade social corporativa por meio dos indicadores Ethos Sebrae-2013, nas ações das empresas investigadas. Ciências Sociais em Perspectiva, v. 15, v. 29, p. $115-138,2016$.

PETRÓLEO BRASILEIRO S.A. Relatório de Sustentabilidade 2013., Rio de Janeiro, 2013, . Disponível em: <www.investidorpetrobras.com.br/>. Acesso em: 8 jan. 2018.

REDAÇÃO BBC BRASIL. Guia da delação da JBS: entenda as acusações que abalaram o mundo político. BBC, Mai. 2017, Disponível em: <http://www.bbc.com/portuguese/brasil-39983080>. Acesso em: 8 jan. 2018.

REDAÇÃO ÉPOCA. Tudo para entender o caso Petrobrás: Um guia para se orientar no escândalo de corrupção que envolve a maior estatal do país e grandes nomes da política nacional. Época, Rio de Janeiro, Set. 2014, Disponível em: <http://epoca.globo.com/ tempo/noticia/2014/09/tudo-para-entender-bo-caso-petrobrasb.html>. Acesso em: 8 jan. 2018.

REDAÇÃO G1. Irmãos Batista revelam como começou esquema na JBS. G1, Rio de Janeiro, Jul. 2017, Disponível em: <http://g1. globo.com/jornal-nacional/noticia/2017/07/irmaos-batista-revelam-como-comecou-esquema-na-jbs.html>. Acesso em: 8 jan. 2018.

REDAÇÃO O GLOBO. Polícia Federal prende executivos das gigantes do setor de carnes JBS e BRF. O Globo, Rio de Janeiro, marMar. 2017, Disponível em: <https://oglobo.globo.com/economia/policia-federal-prende-executivos-das-gigantes-do-setor-de-carnes-jbs-brf-21075354>. Acesso em: 8 jan. 2018.

REDAÇÃO TERRA. Odebrecht: Entenda o maior caso de suborno da história. Terra, Dez. 2016, Disponível em: <https://www. terra.com.br/noticias/brasil/odebrecht-entenda-o-maior-caso-de-suborno-da-historia,2ad4c9f40bf9d93e1b2fba08935c112cokpstq92. html>. Acesso em: 8 jan. 2018.

REDAÇÃO UOL ECONOMIA. Quer entender o que acontece na Petrobrás? Veja esse resumo. Uol Economia, Fev. 2015, Disponível em: <https://economia.uol.com.br/noticias/redacao/2015/02/05/quer-entender-o-que-acontece-na-petrobras-veja-este-resumo.htm>. Acesso em: 8 jan. 2018.

SAENZ, C.; BROWN, H. The disclosure of anticorruption aspects in companies of the construction sector: Main companies worldwide and in Latin America. Journal of Cleaner Production, v. 196, p. 259 - 272, p. 2018.

SIMIONESCU, L., DUMITRESCU, D. Corporate Social Responsibility and Financial Crisis. Journal of Public Administration, Finance and Law, v. 1, p. $31-37,2014$.

SONG, C.; HAN, S. H. Stock Market Reaction to Corporate Crime: Evidence from South Corea. Journal of Business Ethics, v. 143 , n. 2, p. $323-351,2017$

TAGESSON, T. et al. What Explains the Extent and Content of Social and Environmental Disclosures on Corporate Websites: A Study of Social and Environmental Reporting in Swedish Listed Corporations. Corporate Social Responsibility and Environmental Management, v. 16, p. $352-364,2009$.

TEWARI, R.; DAVE, D. Corporate Social Responsibility: Comunication through sustainability reports by indian and multinational companies. Global Business Review, v. 13, v. 3, p. 393 - 405, 2012.

WEYZIG, F. Political and economic arguments for corporate social responsibility: Analysis and a proposition regarding the CSR agenda. Journal of Business Ethics, v. 86, n. 4, p. 417 - 428, 2009. 